\title{
Methanolic Extract of Artemia salina Eggs and Various Fractions in Different Solvents Contain Potent Compounds That Decrease Cell Viability of Colon and Skin Cancer Cell Lines and Show Antibacterial Activity against Pseudomonas aeruginosa
}

\author{
Salman Ul Islam, ${ }^{1}$ Muhammad Bilal Ahmed, ${ }^{1}$ Adeeb Shehzad, ${ }^{2}$ and Young Sup Lee $\mathbb{C}^{1}$ \\ ${ }^{1}$ School of Life Sciences, College of Natural Sciences, Kyungpook National University, 41566, Republic of Korea \\ ${ }^{2}$ Department of Clinical Pharmacy, Institute for Research and Medical Consultations (IRMC), Imam Abdurahman Bin Faisal \\ University, Dammam, Saudi Arabia \\ Correspondence should be addressed to Young Sup Lee; yselee@knu.ac.kr
}

Received 18 January 2019; Revised 10 April 2019; Accepted 22 April 2019; Published 6 May 2019

Academic Editor: Ian Cock

Copyright (C) 2019 Salman Ul Islam et al. This is an open access article distributed under the Creative Commons Attribution License, which permits unrestricted use, distribution, and reproduction in any medium, provided the original work is properly cited.

\begin{abstract}
Artemia salina, crustaceans of class Branchiopoda and order Anostraca, are living and reproducing only in highly saline natural lakes and in other reservoirs where sea water is evaporated to produce salt. Artemia salina eggs can be purchased from pet stores, where they are sold as tropical fish food and a ready source for hatching shrimp. In the current study, methanolic crude extracts and various fractions of Artemia salina eggs extracted in other solvents were tested for effects on cell viability of human colorectal cancer cells (HCT116) and melanoma cells (B16F10) using an MTT (3-(4,5-dimethylthiazol-2-yl)-2,5-diphenyltetrazolium bromide) assay. A methanolic crude extract of eggs was obtained by cold maceration, followed by fractionation to obtain hexane, chloroform, ethyl acetate, $\mathrm{n}$-butanol, and aqueous fractions. The methanolic crude extract decreased cell viability of HCT-116 and B16F10 cell lines at higher concentrations. The other fractions were evaluated using a cell viability assay, and chloroform and hexane showed the highest activity at significantly lower concentrations than did the methanolic fraction. Full scan profiles of the methanolic crude extract and the chloroform and hexane fractions were obtained by gas chromatography mass spectrometry (GC-MS), and the resultant compounds were identified by comparing their spectral data to those available in spectral matching libraries. ROS generation assay, flow cytometry, and western blot analysis provided supporting evidence that the hexane and chloroform fractions induced cell death in HCT116 and B16-F10 cell lines. All fractions were further tested for antibacterial activity against Pseudomonas aeruginosa, among which the hexane fraction showed the highest zone of inhibition on LB nutrient agar plates. This study demonstrated promising anticancer and antibacterial effects of Artemia salina egg extracts. Our results suggest that pure bioactive compounds obtained from Artemia salina eggs can provide new insights into the mechanisms of colon and skin cancer, as well as Pseudomonas aeruginosa inhibition.
\end{abstract}

\section{Introduction}

The popularity of natural products as chemopreventive substances is increasing steadily because of their potential effectiveness and low toxicity [1]. Recently, marine fauna and flora have received significant attention as potent sources of novel chemopreventive agents. High potency antitumor agents have been discovered in marine sources [2]. Strong anticancer activities have been shown in extracts from algae, sponges, and marine cyanobacteria [3-5]. Fucoidans, alginic acids, laminarans, and carrageenans are among the marine-based compounds that exert potent anticancer activities. In addition, miscellaneous polysaccharides extracted from marine animals, fungi, and bacteria have been identified as potential anticancer agents, many of which have been evaluated for further drug development [3]. Anticancer drugs of marine origin available commercially include cytarabine, trabectedin, eribulin mesylate, and brentuximab vedotin $[6,7]$. Many other marine derived substances with potential anticancer activity are currently being investigated in preclinical studies $[5,8]$. 
Artemia salina, also known as brine shrimp, live in highly saline natural lakes, such as the Great Salt Lake in northern Utah and the Caspian Sea, on the rocky coast to the south of San Francisco, and in man-made evaporation ponds used to produce salt from the ocean. They show a remarkable resistance to change and can survive in water with a wide range of salinity. Salty locations are favorable for Artemia salina because there are few predators, but food is also limited in these environments [9]. Artemia salina are used in toxicity assays and for various other academic purposes, because they reproduce rapidly and their natural habitat can be easily replicated. Owing to their low cost and ease of use, adult Artemia salina and their eggs are utilized to feed coral, larval fish, and other crustaceans. Artemia salina and their eggs can also be enriched with proteins, lipids, and other nutrients beneficial to the animal consuming them. Additionally, the nauplii (larvae) can also serve as a carrier of therapeutic substances to treat or prevent diseases [10-12].

Multiple reports are available on the medicinal potential of different marine species and their eggs. For instance, a study demonstrated that hairtail egg, Spanish mackerel egg, and Pacific saury egg contained lysophosphatidic acid and lysophosphatidylcholine, with saturated or unsaturated acyl chains as major lysophospholipid inhibitors, because of which these eggs showed a strong inhibition of lysophospholipase D activity [13]. Studies have shown that omega3 and omega- 6 fatty acids (components of lipid fractions extracted from fish) are associated with the prevention of cardiovascular diseases and cancer [14-16]. Similarly, a study reported that a hexapeptide, Phe-Ile-Met-Gly-ProTyr (FIMGPY), extracted from skate (Raja porosa) cartilage protein hydrolysate, exhibited antiproliferation activities in HeLa cells [17]. To date, however, there are no reports on the medicinal values of Artemia salina eggs.

In this study we analyzed the bioactive compounds present in Artemia salina eggs and investigated their activity against colorectal and skin cancer cell lines and Pseudomonas aeruginosa, which is the most important causative bacterium of burn-associated infections.

\section{Materials and Methods}

2.1. Chemicals and Reagents. Methyl alcohol (product no. 62), n-hexane (product no. 4794), ethyl acetate (product no. 2936), and chloroform (product no. 1268) were purchased from Duksan chemicals, South Korea. 1-butanol (cat\# 33065) was purchased from Honeywell research chemicals. 5-Fluorouracil (cat\# F6627), propidium iodide (PI), and 3(4,5-dimethylthiazol-2-yl)-2,5-diphenyltetrazolium bromide (MTT) were obtained from Sigma-Aldrich (St. Louis, MO, USA). Dihydrorhodamine 123 (DHR 123: cat\# D23806) was purchased from ThermoFisher scientific. Antibodies [cleaved caspase-3 (cat\# sc-22171), cleaved PARP (cat\# sc-56196), and $\beta$-actin (cat\# sc-47778)] were purchased from Santa Cruz Biotechnology (Santa Cruz, CA, USA). 4',6-diamidino-2phenylindole (DAPI) mounting solution (Cat\# H-1200) was purchased from Vector laboratories, USA. All the chemicals and reagents were used as directed by the manufacturers.
2.2. Preparation of Samples. Pure Artemia salina eggs were commercially obtained from Ocean Nutrition ${ }^{\mathrm{TM}}$ (https:// www.oceannutrition.com). The eggs were macerated in pure methanol for $48-72 \mathrm{~h}$. The extraction procedure was repeated three times and the extracts were combined. Methanol was evaporated using a rotary evaporator under reduced pressure to obtain a dried methanolic extract of the eggs. A portion of the methanolic extract was resuspended in methanol and fractionated into solvents with successively increasing polarity. Hexane, chloroform, ethyl acetate, n-butanol, and residual aqueous fractions were obtained.

2.3. Cell Culture. Two cancer cell lines, human colorectal carcinoma cells (HCT116: ATCC ${ }^{\circledR}$ CCL-247 ${ }^{\mathrm{TM}}$ ) and mouse skin melanoma cells (B16-F10: ATCC ${ }^{\circledR}$ CRL-6475 ${ }^{\mathrm{TM}}$ ), were used in the current study. The cells were cultured in Dulbecco's Modified Eagle's Medium (DMEM) with 10\% fetal bovine serum (FBS), L-glutamine, and $1 \%(\mathrm{v} / \mathrm{v})$ penicillinstreptomycin (Gibco, USA) and maintained at $37^{\circ} \mathrm{C}, 5 \% \mathrm{CO} 2$, and $95 \%$ humidity [18].

2.4. Cell Viability Assay. Cell viability was measured by the MTT assay as previously reported previously [19, 20]. Cells were seeded into 96 -well plates at a density of $2 \times$ $10^{5}$ cells/well. Triplicate wells were separately treated across a range of concentrations $(0,5,10,20,40,80,100$, and $250 \mu \mathrm{g} / \mathrm{ml}$ ) of Artemia salina egg crude extract or partially purified fractions. After incubation at $37^{\circ} \mathrm{C}$ with $5 \% \mathrm{CO}_{2}$, the medium was removed and replaced with $200 \mu \mathrm{l}$ of fresh medium with $20 \mu \mathrm{l}$ of $5 \mathrm{mg} / \mathrm{ml}$ MTT solution and incubated for $4 \mathrm{~h}$. The medium with MTT was removed and $200 \mu \mathrm{l}$ of DMSO was added to each well. The plates were then gently agitated until the reaction was uniform in color. OD540 (optical density at $540 \mathrm{~nm}$ ) was determined using a 96-well plate reader. Control cells served as an indicator of $100 \%$ cell viability.

2.5. GC-MS Analysis. GC-MS analysis of the methanol extract and other fractions of Artemia salina eggs was performed using an Agilent system (7890B-5977B GC/MSD with column; J \& W 122-5532DB-5MS). GC-MS conditions used for analysis and identification of Artemia salina egg extracts are summarized in Supplementary Table (available here). The separated compounds were analyzed by GC-MS and retention times for all compounds were determined. The compounds were identified based on comparison of their mass spectra with those of the internal (computer) library W9N11.L.

2.6. Antibacterial Assay. Pseudomonas aeruginosa (Carolina, USA, cat\# 155250A) strains were revived from frozen stocks stored at $-80^{\circ} \mathrm{C}$ by streaking on LB media (Difco LBMiller cat $\# 244620$ ) plates and incubation overnight at $37^{\circ} \mathrm{C}$. Screening of the ethyl acetate, hexane, chloroform, water, and n-butanol fractions for antibacterial activity against Pseudomonas aeruginosa was performed using the paper disc method [21]. Fifty microliters of $2 \mu \mathrm{g} / \mu \mathrm{l}$ stock solutions of the extracts were slowly absorbed into the sterilized paper 
disc and adhered to the surface of the plate on which $10^{6}$ $\mathrm{CFU} / \mathrm{ml}$ Pseudomonas aeruginosa had been inoculated. $1 \%$ silver sulfadiazine was used as a standard. After culturing for $24 \mathrm{~h}$ in an incubator at $37^{\circ} \mathrm{C}$, the clear zones around the disks were measured in millimeters and the antibacterial activities were analyzed and compared. Analysis was performed in triplicate, and the results were reported as the mean $\pm \mathrm{SD}$.

2.7. Mitochondrial ROS Generation Assay. Intracellular ROS was detected using dihydrorhodamine 123 (DHR123), which is an uncharged and nonfluorescent ROS indicator that can passively diffuse across membranes where it is oxidized to cationic rhodamine 123, which localizes to mitochondria and exhibits green fluorescence [22]. To detect ROS generation after treating cells with the hexane and chloroform fractions, $10 \mu \mathrm{M}$ DHR123 was added to the cell culture medium for 20-30 min in the dark. The cells were washed with PBS and nuclei were counterstained with DAPI mounting solution for 5-10 minutes. Cells were then analyzed using a confocal laser scanning platform (DM/R-TCS, Leica) coupled to a microscope (Leitz DM REB).

2.8. Flow Cytometry. Cells were treated with the hexane and chloroform fractions for $24 \mathrm{~h}$. Cells were harvested, washed twice with cold PBS, and fixed with $75 \%$ ethanol at $-20^{\circ} \mathrm{C}$ overnight. After fixation, the cells were washed with cold PBS and incubated in staining buffer $(50 \mu \mathrm{g} / \mathrm{ml}$ PI and 1 $\mathrm{mg} / \mathrm{ml} \mathrm{RNase}$ ) at $37^{\circ} \mathrm{C}$ in the dark for $30 \mathrm{~min}$. Subsequently, the samples were analyzed using a flow cytometer (BD Biosciences, San Diego, CA, USA). The percentages of cells in the $G_{0} / G_{1}, S$, and $G_{2} / M$ phases were calculated using Cell Quest acquisition software (BD Biosciences). Analysis was performed in triplicate, and the results were reported as the mean \pm SD [23].

2.9. Western Blotting. Cells were collected using a cell scraper in PBS and centrifuged at $12,000 \mathrm{rpm}$ for $5 \mathrm{~min}$ to obtain cell pellets. The supernatant were discarded and the cell pellets were resuspended in $200 \mu \mathrm{l}$ of cell lysis buffer $(50 \mathrm{mM}$ Tris, $\mathrm{pH}$ 7.4, 0.5\% NP40, 0.01\% SDS, and protease inhibitor cocktail (Roche, Germany)). After lysis by sonication, total protein in cell lysates was quantified using the Bio-Rad Protein Assay according to the manufacturer's protocol. Samples $(20-40 \mu \mathrm{g})$ were prepared in SDS sample buffer containing $60 \mathrm{mM}$ Tris- $\mathrm{HCl}$ (pH 6.8), 2\% SDS, 10\% glycerol, and $5 \% \beta$-mercaptoethanol, then separated on a $10-12 \%$ SDSPAGE gel, and transferred onto a polyvinylidene fluoride (PVDF) membrane (Amersham, Piscataway, NJ, USA). The membranes were blocked with 3\% albumin (Gendepot, USA) solution for $2 \mathrm{~h}$ at $4^{\circ} \mathrm{C}$. Chemiluminescent signals were developed using Clarity ${ }^{\mathrm{TM}}$ ECL Western Blotting Substrate (Bio-Rad) according to the manufacturer's instructions [18, 24].

2.10. Statistical Analysis. Unless stated otherwise, statistical significance was determined by one-way analysis of variance based on three independent experiments. Differences were considered statistically significant at $\mathrm{p}<.05$.

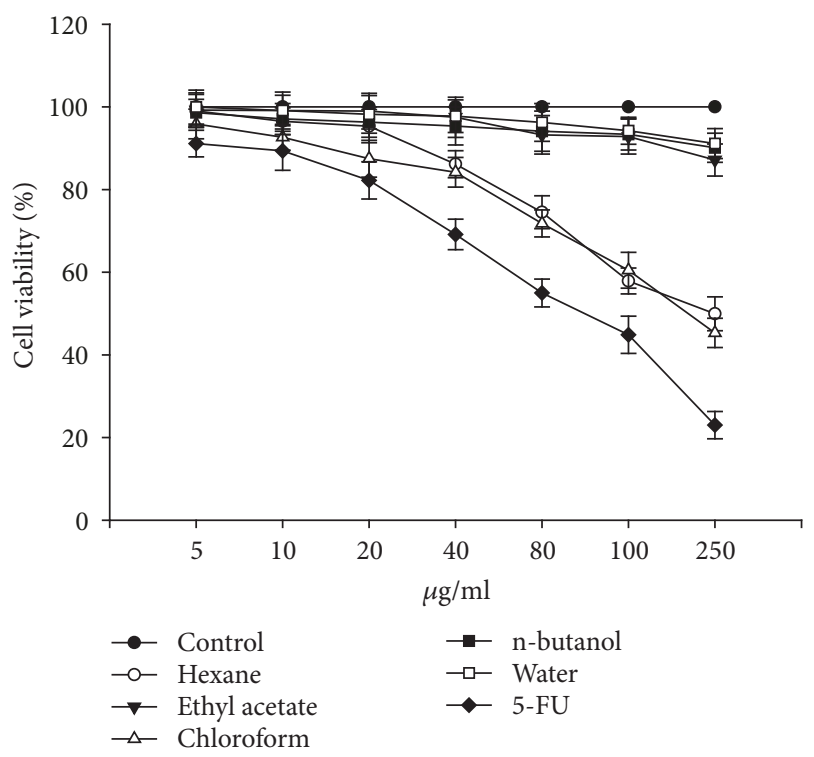

FIGURE 1: Effect of Artemia salina egg extracts on HCT116 cell viability. Triplicate wells were treated across a range of extract concentrations $(0,5,10,20,40,80,100$, and $250 \mu \mathrm{g} / \mathrm{ml})$ for $24 \mathrm{~h}$. 5 fluorouracil (5-FU) was used as standard. Control cells served as an indicator of $100 \%$ cell viability. Hexane and chloroform fractions exhibited the greatest activity.

\section{Results and Discussion}

3.1. Effect of Artemia salina Egg Extracts on HCT116 and B16F10 Cell Viability. To analyze the effect of Artemia salina egg extracts on the viability of HCT116 and B16-F10 cells, we first treated the cells with methanolic crude extracts. Methanolic crude extracts decreased the viability of HCT116 and B16-F10 cells by up to $50 \%$ at concentrations ranging from 500 to $600 \mu \mathrm{g} / \mathrm{ml}$ (data not shown). We further incubated the cells for $24 \mathrm{~h}$ with partially purified fractions (hexane, ethyl acetate, chloroform, n-butanol, and water) at increasing concentrations $(0,5,10,20,40,80,100$, and $250 \mu \mathrm{g} / \mathrm{ml})$ and observed that hexane and chloroform fractions remarkably reduced cell viability of both cells lines. 5 fluorouracil (5FU) was used as standard. Treatment with $250 \mu \mathrm{g} / \mathrm{ml}$ of the hexane and chloroform fractions reduced cell viability of HCT116 cells to $49.94 \%$ and $45.31 \%$, respectively (Figure 1 ). Treatment of B16-F10 cells with $250 \mu \mathrm{g} / \mathrm{ml}$ of the hexane and chloroform fractions reduced cell viability to $47.79 \%$ and $40.68 \%$, respectively (Figure 2). The other fractions evaluated did not reduce cell viability of either cell line. For example, $250 \mu \mathrm{g} / \mathrm{ml}$ of the aqueous fraction resulted in only a $15.87 \%$ reduction in B16-F10 cell viability (Figure 2). These cell viability data showed that the hexane and chloroform fractions effectively reduced cell viability of the HCT116 and B16-F10 cell lines, indicating the presence of bioactive compounds in these fractions, which could be further purified using more intricate extraction techniques.

3.2. Identification of Chemical Constituents. GC-MS analysis was used to identify bioactive compounds in Artemia salina egg methanolic crude extract and hexane and chloroform 


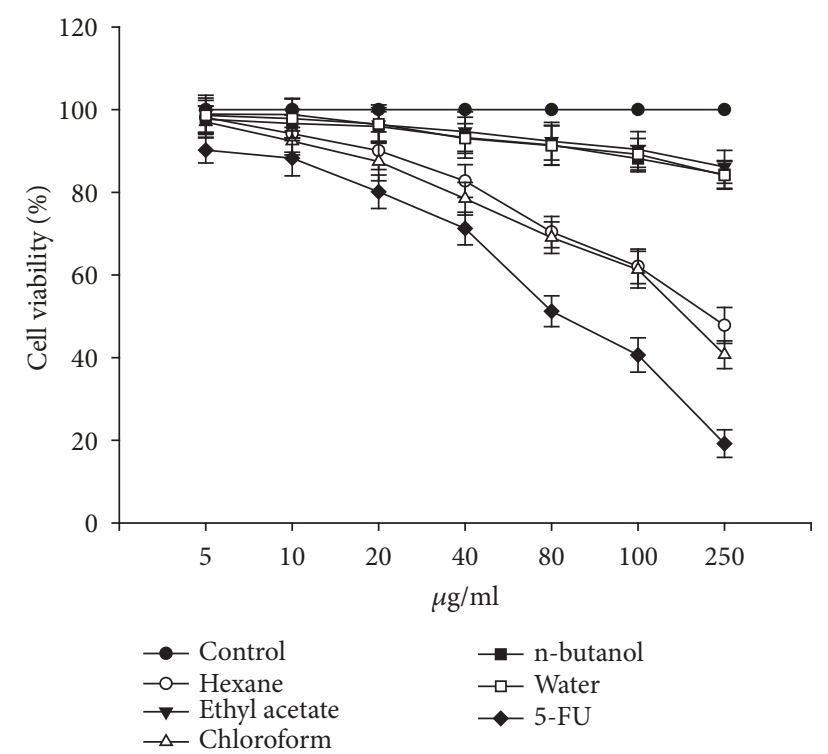

FIgURE 2: Effect of Artemia salina egg extracts on B16-F10 cell viability. Cells were treated in triplicate cross a range of extract concentrations $(0,5,10,20,40,80,100$, and $250 \mu \mathrm{g} / \mathrm{ml})$ for $24 \mathrm{~h}$. 5 -FU was used as standard. Control cells served as an indicator of $100 \%$ cell viability. Hexane and chloroform fractions exhibited the greatest activity.

fractions $[25,26]$. Hexane and chloroform fractions were chosen for compound identification based on cell viability experiment results. GC-MS analysis of the methanolic extract of Artemia salina eggs showed several peaks which indicated the presence of chemical constituents (Figure 3(a)). Comparison of the mass spectra of the constituents with those in the internal (computer) library W9N11.L resulted in identification of four chemical constituents: dibutyl phthalate, 9-octadecenoic acid methyl ester, Oleic acid, and di(2-ethylhexyl)phthalate (Figure 3(b)). Dibutyl phthalate has been previously reported to exert anticancer activity against lung adenocarcinoma (SPC-A-1) cells and human papillomavirus-related endocervical adenocarcinoma (BEL7402) cells [27]. Another study reported that dibutyl phthalate inhibited growth of human lung carcinoma (A549) cells [28]. Furthermore, dibutyl phthalate showed significant activity against the gram negative bacteria Klebsiella pneumonia, Proteus mirabilis, and Pseudomonas aeruginosa at a concentration of $40 \mu \mathrm{L} / \mathrm{m}$ [29]. 9-octadecenoic acid methyl ester has been shown to exert antioxidant and anticancer activities [30-32]. Several studies have reported that oleic acid reduced proliferation of prostate carcinoma (PC-3) cells [33]. In addition, oleic acid can induce Staphylococcus aureus death through a mechanism involving bacterial lipids [34]. Studies have shown that different staphylococci species are not capable of metabolizing oleic acid and that oxidation products of oleic acid are highly toxic to bacterial cells $[35,36]$. $\mathrm{Di}(2$ ethylhexyl)phthalate has been reported to exert antileukemic activity as evidenced by growth inhibition in three human leukemic cell lines, K562, HL60, and U937, at a low concentration [37]. Five major compounds with previously established bioactivity were identified in the hexane (Figures 4(a) and 4(b)) and chloroform (Figures 5(a) and 5(b)) fractions. These compounds were previously shown to exert antimycobacterial, antitumor, opioid receptor antagonistic, antifungal, anti-inflammatory, and antimalarial activities [38-45]. For example, 2,4-bis(1, 1-dimethylethyl)phenol has been shown to effectively control biofilms of Serratia marcescens [43]. Indole-3-carboxaldehyde efficiently inhibited human liver carcinoma (HepG2), human breast adenocarcinoma (MCF7), human ductal breast epithelial tumor (T47D), A549, human cervix adenocarcinoma (HeLa), and mouse fibroblast (L929) cells with considerable selectivity [38]. Moreover, a study evaluated the effect of naloxone on human breast cancer cell growth and progression in a mouse model of human triplenegative breast cancer generated by injecting MDA.MB231 (estrogen receptor-negative human breast carcinoma cells subcutaneously into mice. This study demonstrated proliferation of MDA.MB231 cells was inhibited, and cell death increased, in a dose-dependent manner in response to naloxone. In vivo studies showed that tumors in mice treated with naloxone were significantly smaller than those observed in the control groups [40]. Complete details of all identified compounds along with their activities are summarized in Table 1 . The presence of various bioactive compounds in Artemia salina eggs justifies their potential use for treatment of various ailments. However, isolation of individual chemical constituents and subsequent evaluation of biological activity will allow for further characterization of therapeutic potential of Artemia salina egg extracts. Based on our results, Artemia salina eggs contain various bioactive compounds which may be of pharmaceutical importance.

3.3. Apoptosis-Inducing Potential. As we observed the presence of previously reported anticancer agents in Artemia salina egg extracts, we hypothesized that these extracts could induce apoptosis in cancer cell lines. Furthermore, our results in this study showed that the hexane and chloroform fractions of Artemia salina egg extracts potently decreased viability of HCT116 and B16-F10 cells. Reactive oxygen species (ROS) generation is related to induction of apoptosis in cancer cells $[46,47]$. As such, we analyzed ROS generation using a DHR 123 probe after treating cells with either the hexane or chloroform fractions. 5-FU was used as standard. Compared to untreated cells, increased rhodamine 123 fluorescence was observed in hexane and chloroform fraction-treated cells (Figure 6(a)). Next, we incubated cells with $100 \mu \mathrm{g} / \mathrm{ml}$ of hexane and chloroform fractions for $24 \mathrm{~h}$ and then measured the sub- $G_{1}$ fraction from fixed nuclei by PI staining and flow cytometry. As shown in Figure 6(b), the hexane and chloroform fractions increased the proportion of cell death ( $17.2 \%$ and $19.4 \%$ respectively) at the sub- $G_{1}$ phase of the cell cycle. Western blot analysis was performed to determine caspase- 3 activation in cells treated with the hexane and chloroform fractions. We observed a reduction of the $32 \mathrm{kDa}$ caspase- 3 zymogen, an increase in the p1l subunit of caspase-3, and increased cleaved PARP. These results indicated that caspase-3 was activated in HCT116 and B16F10 cells in response to treatment with the hexane and chloroform fractions (Figure 6(c)). Collectively, these results suggest that the hexane and chloroform fractions induced 


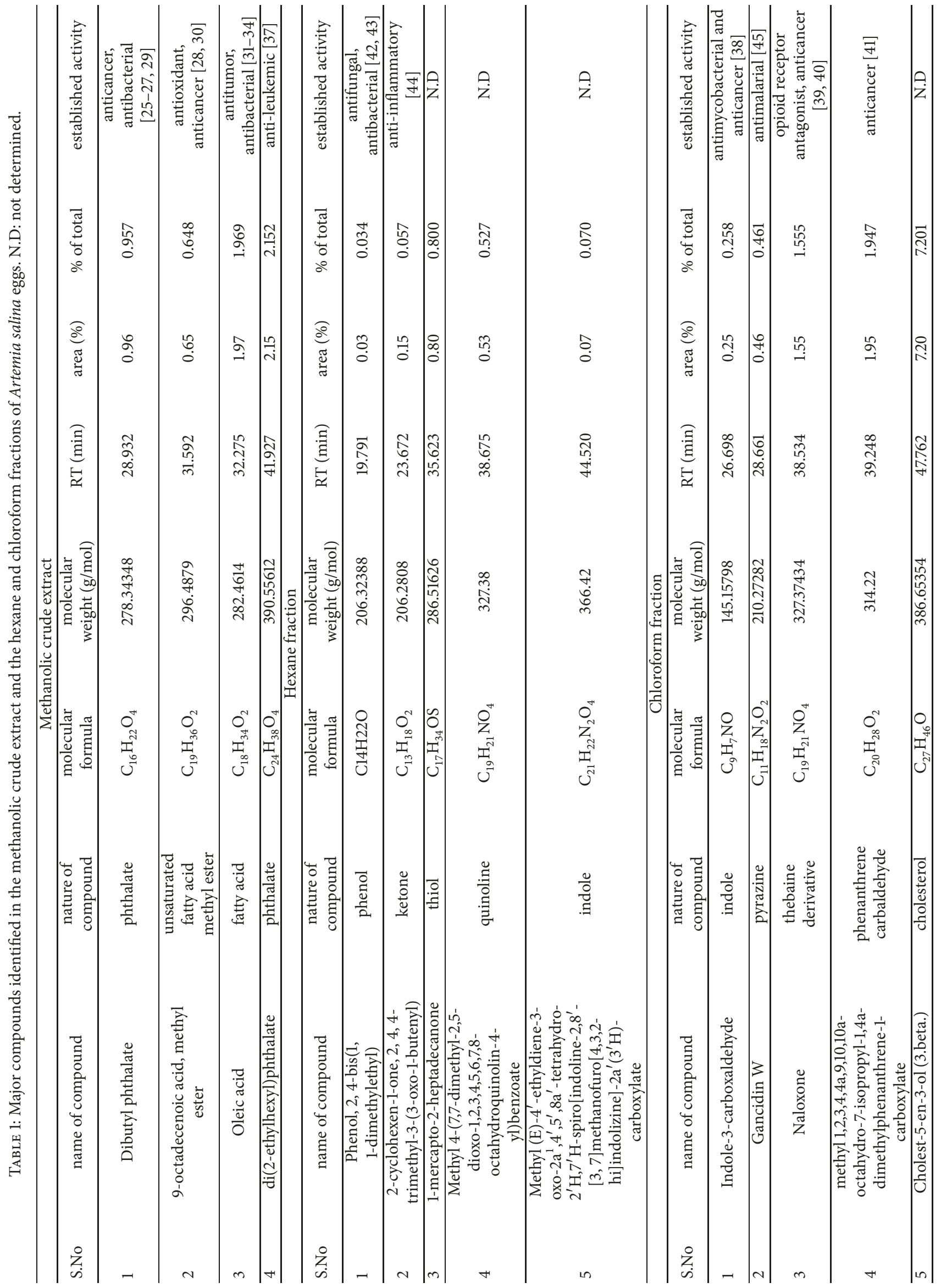




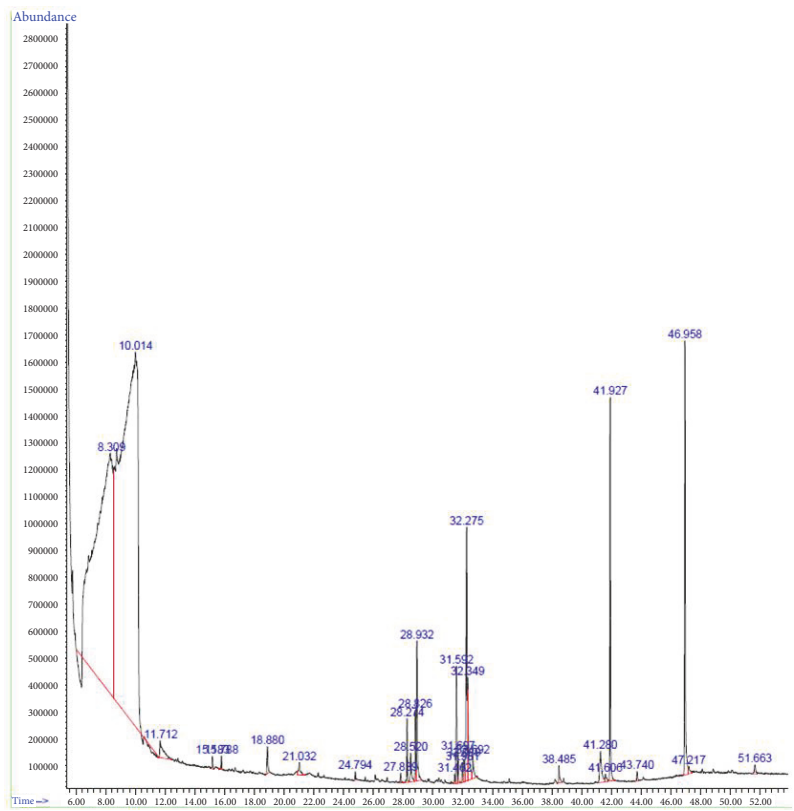

(a)
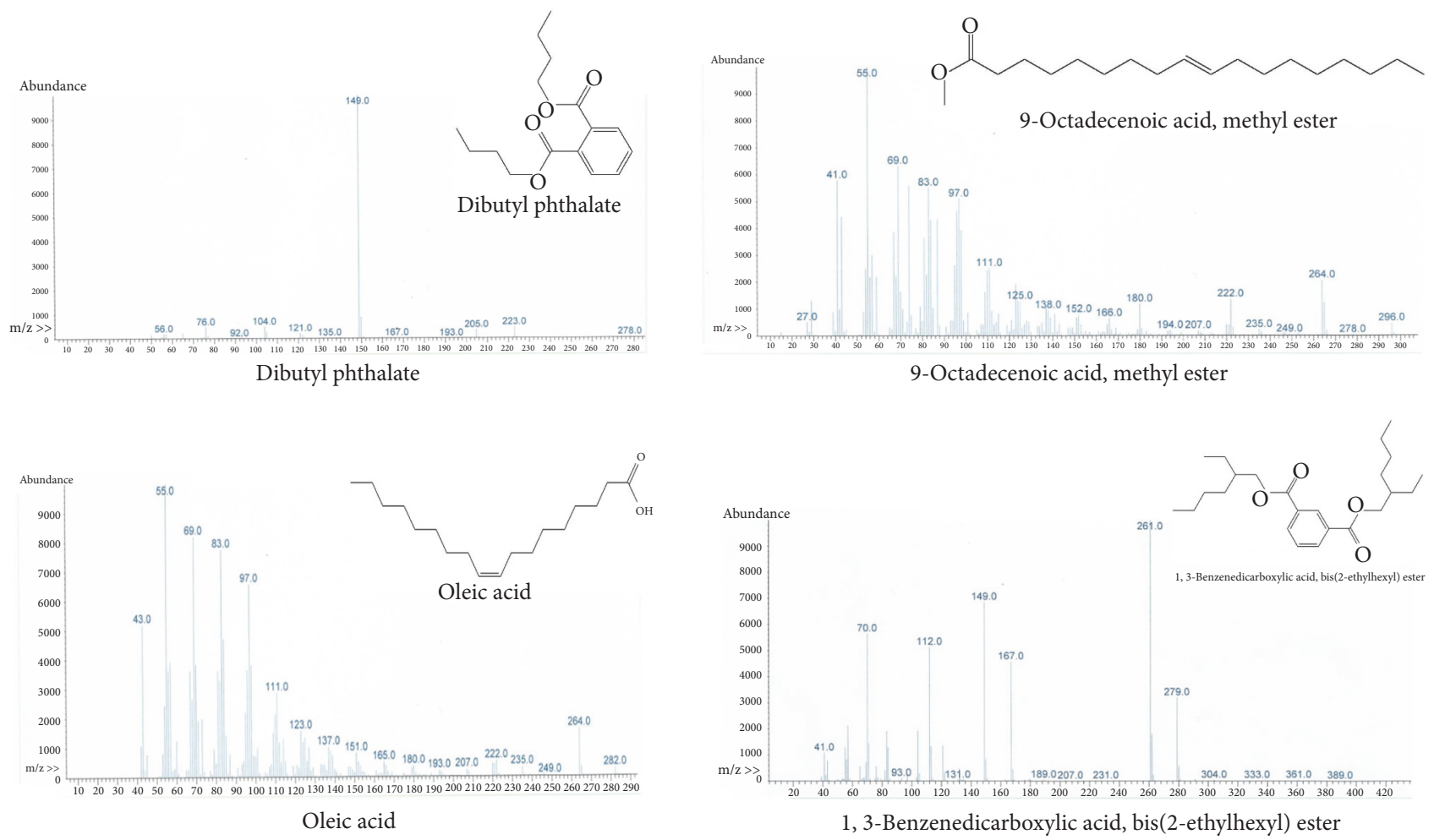

(b)

Figure 3: GC-MS analysis of methanolic crude extract of Artemia salina eggs. (a) Chromatogram of the methanolic crude extract of Artemia salina eggs. (b) Compounds identified in the methanolic crude extract of Artemia salina eggs. Details of these compounds are summarized in Table 1.

oxidative stress-induced apoptosis in HCT116 and B16-F10 cells through activation of caspase- 3 .

3.4. Antibacterial Activity against Pseudomonas aeruginosa. Using GC-MS analysis, we observed various compounds in Artemia salina eggs such as dibutyl phthalate, oleic acid, and phenol, 2, 4-bis(1, 1-dimethylethyl), for which antibacterial activity had previously been reported (Table 1). Based on these results, we evaluated activity of Artemia salina egg extracts against Pseudomonas aeruginosa, which 


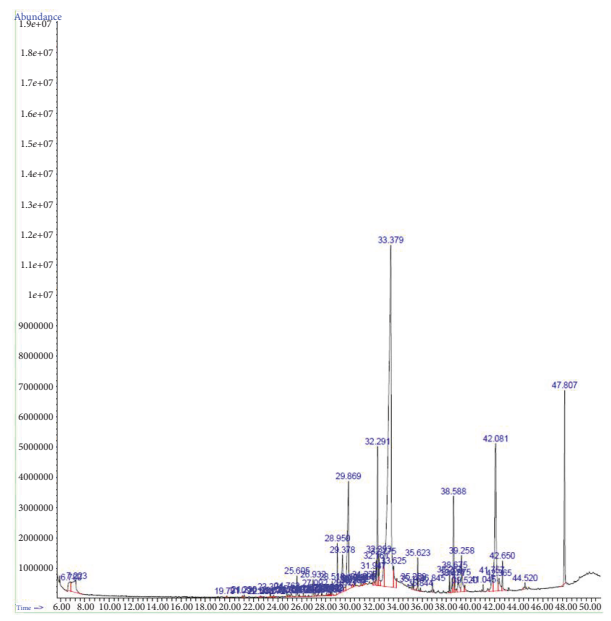

(a)

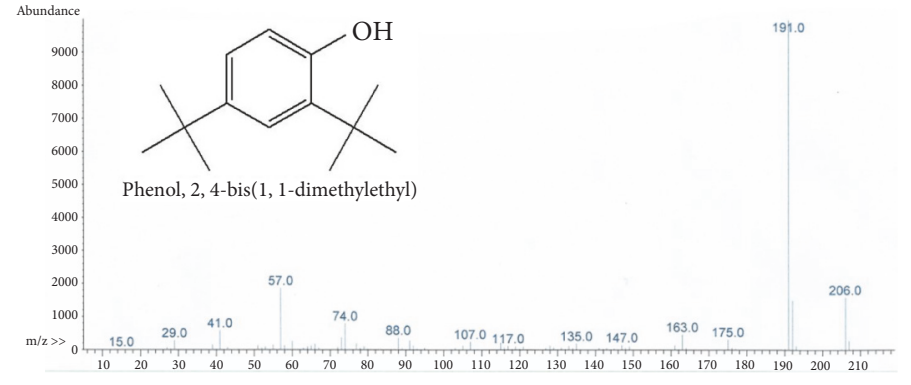

Phenol, 2, 4-bis(1, 1-dimethylethyl)
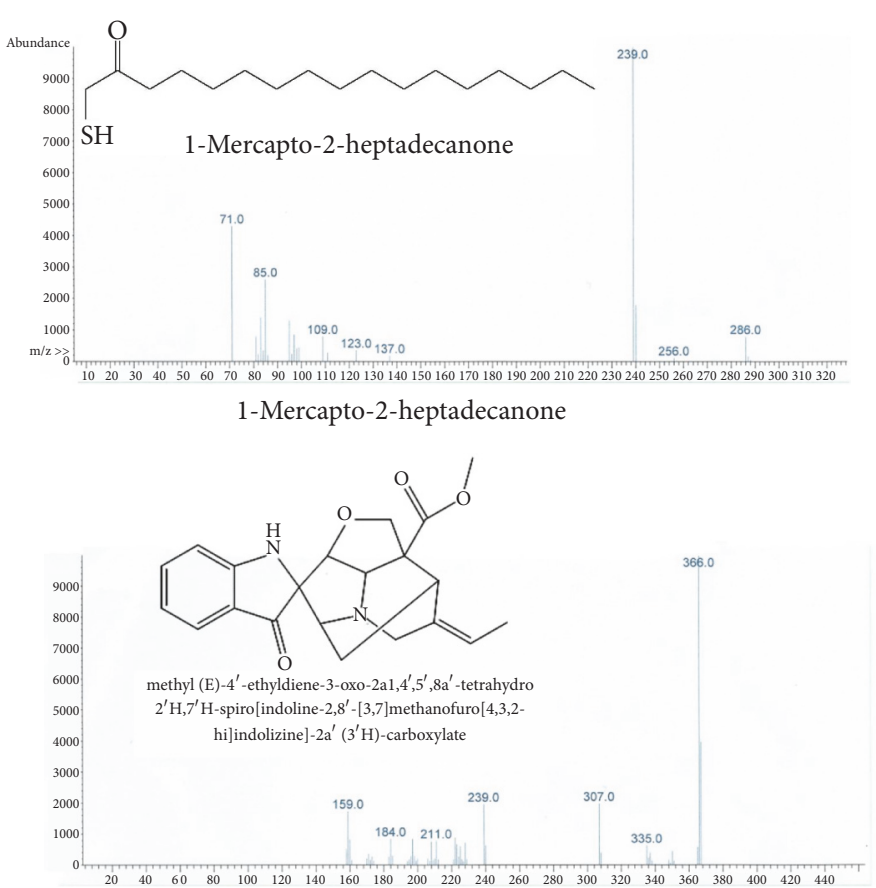

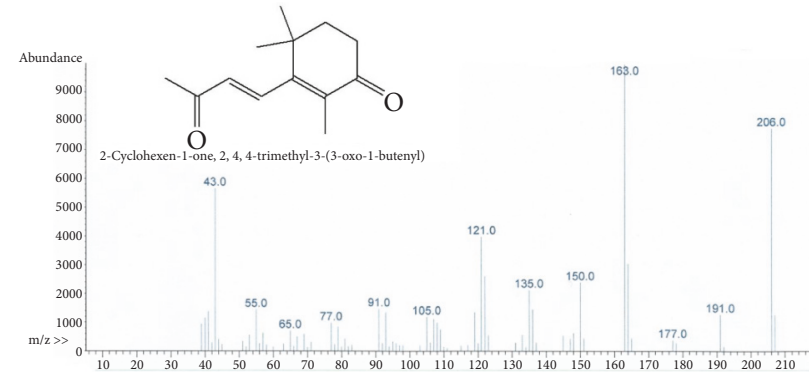

2-Cyclohexen-1-one, 2, 4, 4-trimethyl-3-(3-oxo-1-butenyl)

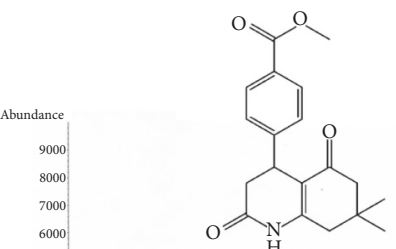

Methyl 4-(7,7-dimethyl-2,5-dioxo-1, 23,4,5,6,7,8-

octahydroquinolin-4-yl)benzoate

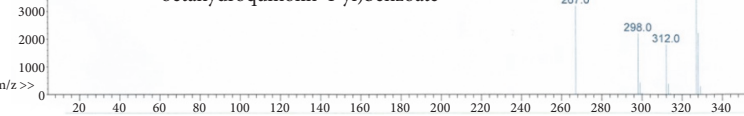

Methyl 4-(7,7-dimethyl-2,5-dioxo-1,2,3,4,5,6,7,8-

octahydroquinolin-4-yl)benzoate

methyl (E)-4' -ethyldiene-3-oxo-2a1, $4^{\prime}, 5^{\prime}, 8 \mathrm{a}^{\prime}$-tetrahydro-2 $\mathrm{H}, 7^{\prime} \mathrm{H}$-spiro[indoline-2, $8^{\prime}$ -

[3,7]methanofuro[4,3,2-hi]indolizine]-2a' $\left(3^{\prime} \mathrm{H}\right)$-carboxylate

(b)

FIGURE 4: GC-MS analysis of the hexane fraction of the methanolic crude extract. (a) Chromatogram of the hexane fraction of the methanolic crude extract. (b) Compounds identified in the hexane fraction of methanolic crude extract. Details regarding these compounds are summarized in Table 1. 


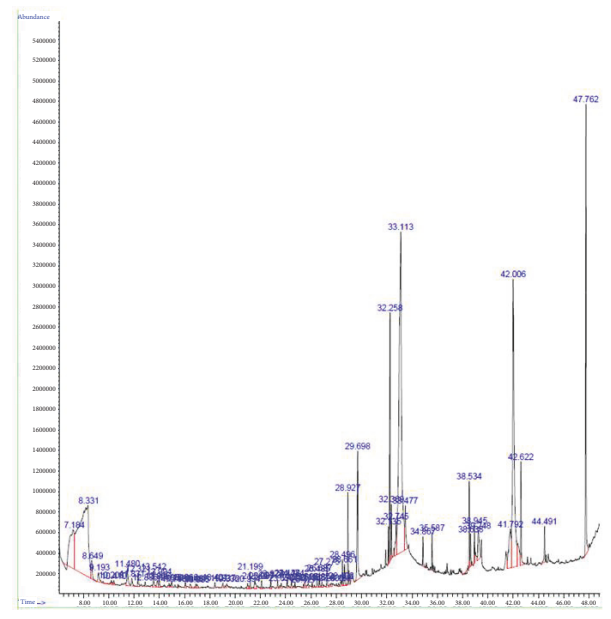

(a)
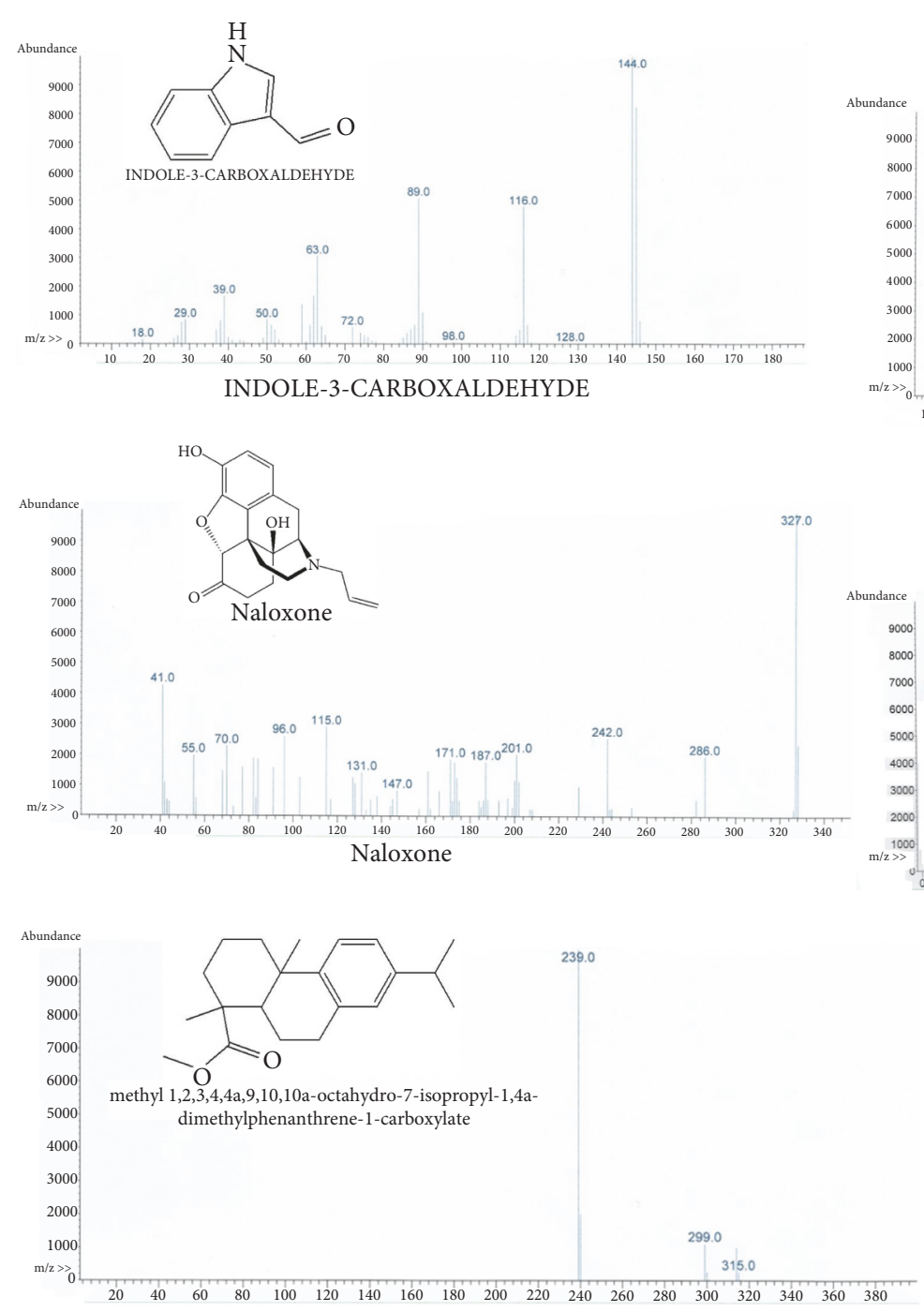

methyl 1,2,3,4,4a,9,10,10a-octahydro-7-isopropyl-1,4a-dimethylphenanthrene-1-carboxylate

(b)

FiguRE 5: GC-MS analysis of the chloroform fraction of the methanolic crude extract. (a) Chromatogram of the chloroform fraction of the methanolic crude extract. (b) Compounds identified in the chloroform fraction of the methanolic crude extract. Details regarding these compounds are summarized in Table 1. 


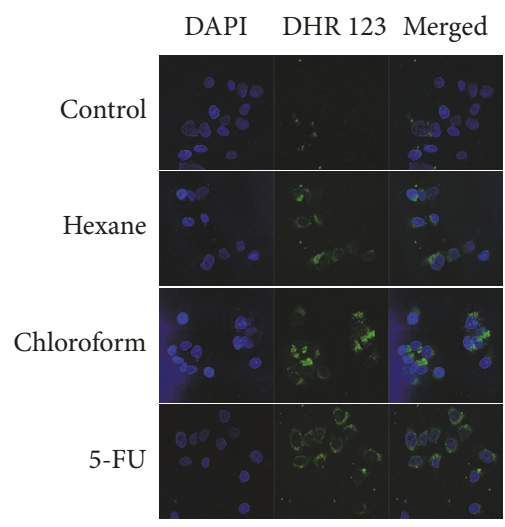

(a)

Control Hexane
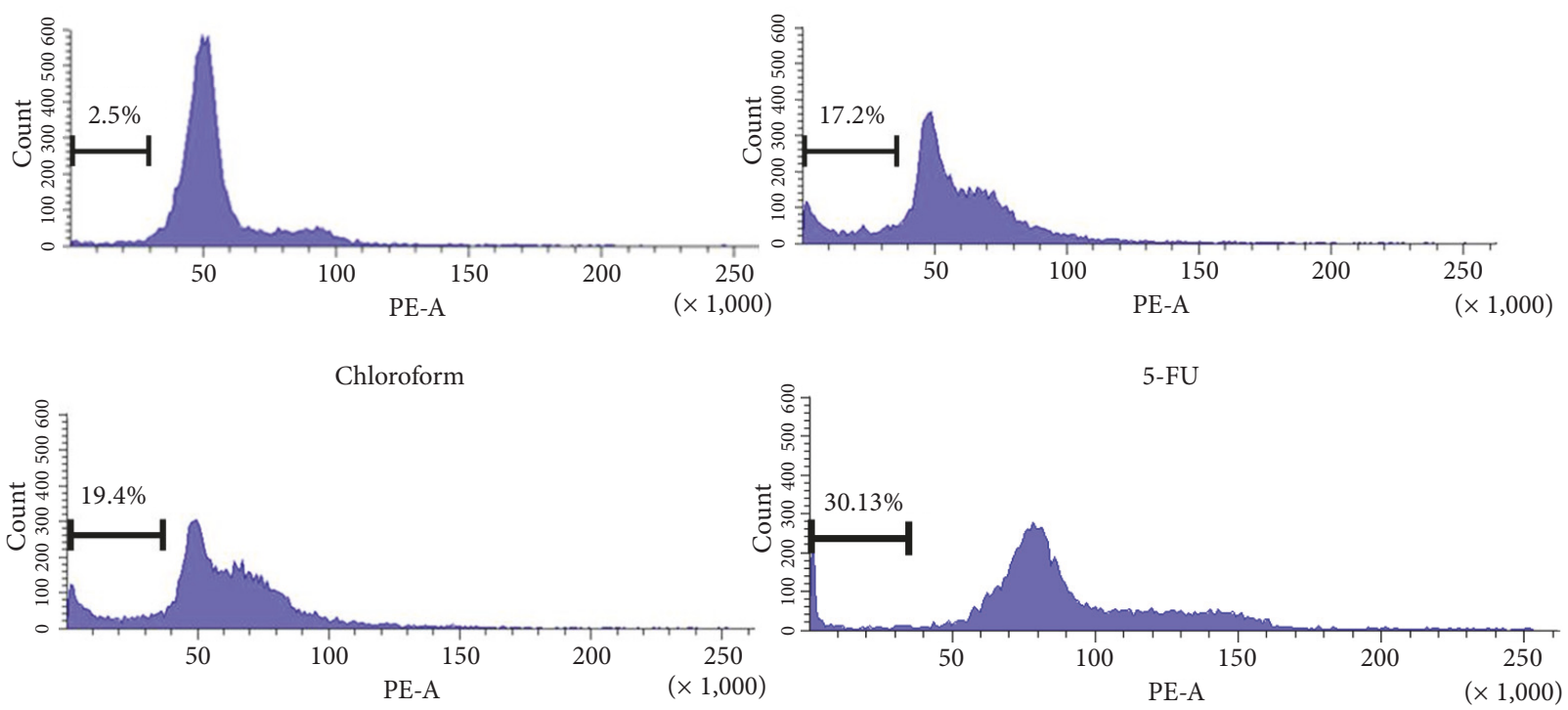

(b)

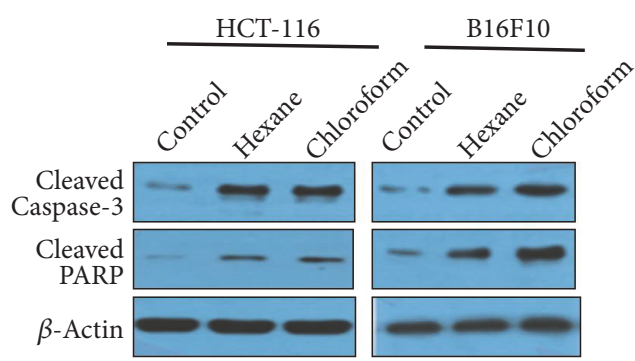

(c)

FIGURE 6: Hexane and chloroform fractions of the methanolic extract induced apoptosis in HCT116 and B16-F10 cells. (a) Intracellular ROS generation was determined by treating cells with $100 \mu \mathrm{g} / \mathrm{ml}$ hexane and chloroform fractions for $24 \mathrm{~h}$ and then incubating them with DHR123 for 20-30 min. Images were obtained using a fluorescence microscope, with excitation and emission wavelengths of 500 and 536 $\mathrm{nm}$, respectively. 5-FU was used as standard. (b) Cells were treated with $10 \mu \mathrm{g} / \mathrm{ml}$ hexane and chloroform fractions. Cells were collected, fixed with $70 \%$ ethanol overnight at $-20^{\circ} \mathrm{C}$, and then stained with PI. DNA content was analyzed by flow cytometry. 5 -FU was used as standard. (c) Cellular proteins were extracted using cell lysis buffer. Proteins were quantified by Bradford assay, and equal amount of proteins was loaded onto SDS-PAGE gels. Electrophoresis was conducted at a constant voltage of 100V for 140 min. Proteins were then transferred onto nitrocellulose (NC) membranes. NC membranes were blocked with 3\% BSA for $1 \mathrm{~h}$ at room temperature. NC membranes were then incubated with specific antibodies (1:1000) for cleaved caspase- 3 and cleaved PARP overnight at $4{ }^{\circ} \mathrm{C}$. NC membranes were washed with TBST for 40 min and then incubated with HRP-conjugated anti-rabbit or anti-mouse secondary antibodies (1:2000). Chemiluminescent signals were developed using Clarity ${ }^{\mathrm{TM}}$ ECL Western Blotting Substrate. Actin was used as internal control in all experiments. 

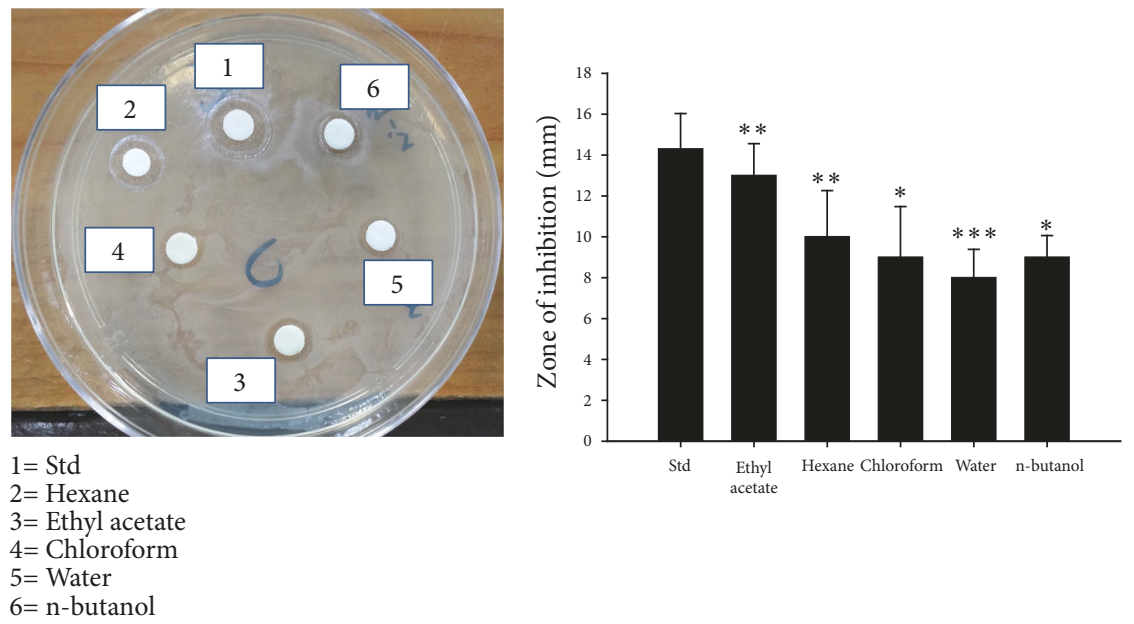

Figure 7: Antibacterial activity against Pseudomonas aeruginosa. Pseudomonas aeruginosa $\left(10^{6} \mathrm{CFU} / \mathrm{ml}\right)$ was cultured on LB agar plates. Fifty microliters of $2 \mu \mathrm{g} / \mu \mathrm{l}$ stock solutions of the hexane and chloroform extracts was slowly absorbed into the sterilized paper disc (diameter: $8 \mathrm{~mm}$ ) and adhered to the surface of the plate. One percent silver sulfadiazine was used as a standard. The clear zone around the disk was measured in millimeters. Analysis was performed in triplicate, and the results were reported as the mean $\pm \mathrm{SD} . * \mathrm{P}<0.05 ; * * \mathrm{P}<0.01 ; * * * \mathrm{P}$ $<0.01$.

is the primary bacterium involved in burn infections. Burnassociated infections caused by Pseudomonas aeruginosa are among the most severe infections, causing major delays in burn patient recovery and potential death [48-50]. To analyze the antibacterial activity of various fractions against Pseudomonas aeruginosa, we cultured the bacterium on LB agar plates and used the paper disc method [21]. Fifty microliters of $2 \mu \mathrm{g} / \mu \mathrm{l}$ stock solutions of the extracts was slowly absorbed into the sterilized paper disc and adhered to the surface of the plate. $1 \%$ silver sulfadiazine was used as a standard. After culturing for $24 \mathrm{~h}$ in an incubator at $37^{\circ} \mathrm{C}$, the clear zone around the disk was measured and antibacterial activities were analyzed and compared. We observed that the hexane fraction showed the greatest clear zone $(13 \mathrm{~mm})$, which was very close to that of the standard $(14.3 \mathrm{~mm})$ (Figure 7). The clear zones of ethyl acetate, chloroform, water, and n-butanol were $10 \mathrm{~mm}, 9 \mathrm{~mm}, 8 \mathrm{~mm}$, and $9 \mathrm{~mm}$, respectively (Figure 7 ). These data suggested that Artemia salina egg extracts compounds with antibacterial activity against Pseudomonas aeruginosa, which indicates that these extracts may have potential for treatment of burn-associated infections after further purification.

\section{Conclusion}

The current study explored the activity of Artemia salina egg extracts against cancer cell lines and Pseudomonas aeruginosa. Artemia salina egg extracts exhibited potent inhibitory activity against HCT116 and B16-F10 cells. The hexane and chloroform fractions potently decreased the viability of both cell lines. Collectively, 14 compounds were identified from the methanolic crude extract, and the hexane, and chloroform fractions, by GC-MS, many of which were previously associated with anticancer, antioxidant, antimycobacterial, opioid receptor antagonist, antifungal, and anti-inflammatory activities. Artemia salina egg extracts induced apoptosis in the HCT116 and B16-F10 cells lines and showed antibacterial activity against Pseudomonas aeruginosa. The hexane fraction exerted the strongest antibacterial activity. Therefore, the hexane and chloroform fractions of Artemia salina eggs may provide potential therapeutic benefit for the treatment of colorectal cancer, skin cancer, and burn-associated infections.

\section{Data Availability}

The data used to support the findings of this study are available from the corresponding author upon request.

\section{Conflicts of Interest}

The authors declare no conflicts of interest.

\section{Acknowledgments}

This research was supported by the National Research Foundation of Korea (NRF) grant funded by the Korea government (MSIT) (NRF-2016R1A2B4012677 and NRF2019R1A2C1003003).

\section{Supplementary Materials}

Supplementary Table: GC/MS conditions used for analysis and identification of Artemia salina eggs extracts. (Supplementary Materials)

\section{References}

[1] J. A. Crowell, "The chemopreventive agent development research program in the division of cancer prevention of the us national cancer institute: an overview," European Journal of Cancer, vol. 41, no. 13, pp. 1889-1910, 2005. 
[2] M. Heinrich, J. Barnes, S. Gibbons, and E. Williamson, Fundamentals of Pharmacognosy and Phytotherapy, Dr Duke's Phytochemical and Ethnobotanical Databases, Churchill Livingstone an imprint of Elsevier Science Limited, London, UK, 2004.

[3] S. N. Fedorov, S. P. Ermakova, T. N. Zvyagintseva, and V. A. Stonik, "Anticancer and cancer preventive properties of marine polysaccharides: some results and prospects," Marine Drugs, vol. 11, no. 12, pp. 4876-4901, 2013.

[4] F. A. Valeriote, K. Tenney, J. Media et al., "Discovery and development of anticancer agents from marine sponges: perspectives based on a chemistry-experimental therapeutics collaborative program," Journal of Experimental Therapeutics and Oncology, vol. 10, no. 2, pp. 119-134, 2012.

[5] M. Costa, M. Garcia, J. Costa-Rodrigues et al., "Exploring bioactive properties of marine cyanobacteria isolated from the portuguese coast: high potential as a source of anticancer compounds," Marine Drugs, vol. 12, no. 1, pp. 98-114, 2014.

[6] S. Indumathy and C. R. Dass, "Finding chemo: the search for marine-based pharmaceutical drugs active against cancer," Journal of Pharmacy and Pharmacology, vol. 65, no. 9, pp. 12801301, 2013.

[7] D. J. Newman and G. M. Cragg, "Marine-sourced anti-cancer and cancer pain control agents in clinical and late preclinical development," Marine Drugs, vol. 12, no. 1, pp. 255-278, 2014.

[8] G. Schwartsmann, A. B. da Rocha, R. G. S. Berlinck, and J. Jimeno, "Marine organisms as a source of new anticancer agents," The Lancet Oncology, vol. 2, no. 4, pp. 221-225, 2001.

[9] K. E. Banister and A. C. Campbell, "The encyclopedia of aquatic life: facts on file," 1985.

[10] P. Lavens and P. Sorgeloos, "Manual on the production and use of live food for aquaculture: Food and Agriculture Organization (FAO)," 1996.

[11] J. Dhont and G. Van Stappen, "Biology, tank production and nutritional value of Artemia," Live Feeds in Marine Aquaculture, pp. 65-121, 2003.

[12] D. A. Bengtson, P. Léger, and P. Sorgeloos, "Use of artemia as a food source for aquaculture," Artemia Biology, vol. 11, pp. 255286, 1991.

[13] X.-W. Liu, H. J. Shim, C. W. Son et al., "Inhibition of lysophospholipase D activity by fish egg extracts," European Food Research and Technology, vol. 228, no. 3, pp. 411-416, 2009.

[14] H. W. Renner and H. Delincee, "Different antimutagenic actions of linoleic- and linolenic acid derivatives on busulfan-induced genotoxicity in Chinese hamsters," Nutrition Research, vol. 8, no. 6, pp. 635-642, 1988.

[15] K. L. Fritsche and P. V. Johnston, "Effect of dietary $\alpha$-linolenic acid on growth, metastasis, fatty acid profile and prostaglandin production of two murine mammary adenocarcinomas," Journal of Nutrition, vol. 120, no. 12, pp. 1601-1609, 1990.

[16] D. P. Rose and J. M. Connolly, "Omega-3 fatty acids as cancer chemopreventive agents," Pharmacology \& Therapeutics, vol. 83, no. 3, pp. 217-244, 1999.

[17] X. Pan, Y.-Q. Zhao, F.-Y. Hu, C.-F. Chi, and B. Wang, "Anticancer activity of a hexapeptide from skate (Raja porosa) cartilage protein hydrolysate in HeLa cells," Marine Drugs, vol. 14, no. 8, article no. 153, 2016.

[18] S. U. Islam, A. Shehzad, J. K. Sonn, and Y. S. Lee, "PRPF overexpression induces drug resistance through actin cytoskeleton rearrangement and epithelial-mesenchymal transition," Oncotarget, vol. 8, no. 34, pp. 56659-56671, 2017.
[19] C. Focaccetti, A. Bruno, E. Magnani et al., "Effects of 5fluorouracil on morphology, cell cycle, proliferation, apoptosis, autophagy and ros production in endothelial cells and cardiomyocytes," PLoS ONE, vol. 10, no. 2, Article ID e0115686, 2015.

[20] D. Sharma, A. Pramanik, and P. K. Agrawal, "Evaluation of bioactive secondary metabolites from endophytic fungus Pestalotiopsis neglecta BAB-5510 isolated from leaves of Cupressus torulosa D.Don," 3 Biotech, vol. 6, no. 2, article no. 210, 2016.

[21] M. Balouiri, M. Sadiki, and S. K. Ibnsouda, "Methods for in vitro evaluating antimicrobial activity: a review," Journal of Pharmaceutical Analysis, vol. 6, no. 2, pp. 71-79, 2016.

[22] N. Zurgil, Y. Shafran, E. Afrimzon, D. Fixler, A. Shainberg, and M. Deutsch, "Concomitant real-time monitoring of intracellular reactive oxygen species and mitochondrial membrane potential in individual living promonocytic cells," Journal of Immunological Methods, vol. 316, no. 1-2, pp. 27-41, 2006.

[23] S. U. Islam, A. Shehzad, and Y. S. Lee, "Prostaglandin E2 inhibits resveratrol-induced apoptosis through activation of survival signaling pathways in HCT-15 cell lines," Animal Cells and Systems, vol. 19, no. 6, pp. 374-384, 2015.

[24] S. U. Islam, M. B. Ahmed, S. J. Lee et al., "PRP4 kinase induces actin rearrangement and epithelial-mesenchymal transition through modulation of the actin-binding protein cofilin," Experimental Cell Research, vol. 369, no. 1, pp. 158-165, 2018.

[25] G. Ghosh, P. Panda, M. Rath, A. Pal, T. Sharma, and D. Das, "GC-MS analysis of bioactive compounds in the methanol extract of Clerodendrum viscosum leaves," Pharmacognosy Research, vol. 7, no. 1, pp. 110-113, 2015.

[26] B. P. Ezhilan and R. Neelamegam, "GC-MS analysis of phytocomponents in the ethanol extract of Polygonum chinense L.," Pharmacognosy Research, vol. 4, no. 1, pp. 11-14, 2012.

[27] T. Wang, Y. Yuan, J. Wang, C. Han, and G. Chen, "Anticancer activities of constituents from the stem of Polyalthia rumphii," Pakistan Journal of Pharmaceutical Sciences, vol. 25, no. 2, pp. 353-356, 2012.

[28] H.-F. Hsu, K.-H. Huang, K.-J. Lu et al., “Typhonium blumei extract inhibits proliferation of human lung adenocarcinoma A549 cells via induction of cell cycle arrest and apoptosis," Journal of Ethnopharmacology, vol. 135, no. 2, pp. 492-500, 2011.

[29] E. Khatiwora, V. B. Adsul, M. Kulkarni, N. Deshpande, and R. Kashalkar, "Antibacterial activity of dibutyl phthalate: a secondary metabolite isolated from ipomoea carnea stem," Journal of Pharmacy Research, vol. 5, pp. 150-152, 2012.

[30] S. F. Asghar and M. I. Choudahry, "Gas chromatography-mass spectrometry (GC-MS) analysis of petroleum ether extract (oil) and bio-assays of crude extract of Iris germanica," International Journal of Genetics and Molecular Biology, vol. 3, no. 7, pp. 95100, 2011.

[31] R. Hema, S. Kumaravel, and J. Alagusundaram, "GC/MS determination of bioactive components of Murraya koenigii," Journal of American Science, vol. 7, pp. 80-83, 2011.

[32] Y. L. Ha, N. K. Grimm, and M. W. Pariza, "Newly recognized anticarcinogenic fatty acids: identification and quantification in natural and processed cheeses," Journal of Agricultural and Food Chemistry, vol. 37, no. 1, pp. 75-81, 1989.

[33] M. Hughes-Fulford, Y. Chen, and R. R. Tjandrawinata, "Fatty acid regulates gene expression and growth of human prostate cancer PC-3 cells," Carcinogenesis, vol. 22, no. 5, pp. 701-707, 2001. 
[34] N. R. Chamberlain, B. G. Mehrtens, Z. Xiong, F. A. Kapral, J. L. Boardman, and J. I. Rearick, "Correlation of carotenoid production, decreased membrane fluidity, and resistance to oleic acid killing in Staphylococcus aureus 18Z," Infection and Immunity, vol. 59, no. 12, pp. 4332-4337, 1991.

[35] A. G. James, J. Casey, D. Hyliands, and G. Mycock, "Fatty acid metabolism by cutaneous bacteria and its role in axillary malodour," World Journal of Microbiology and Biotechnology, vol. 20, no. 8, pp. 787-793, 2004.

[36] S. R. Clarke, R. Mohamed, L. Bian et al., "The Staphylococcus aureus surface protein IsdA mediates resistance to innate defenses of human skin," Cell Host \& Microbe, vol. 1, no. 3, pp. 199-212, 2007.

[37] K. H. Lee, J. H. Kim, D. S. Lim, and C. H. Kim, "Anti-leukaemic and anti-mutagenic effects of di(2-ethylhexyl)phthalate isolated from Aloe vera Linne," Journal of Pharmacy and Pharmacology, vol. 52, no. 5, pp. 593-598, 2000.

[38] V. Mashayekhi, K. Haj Mohammad Ebrahim Tehrani, P. Azerang, S. Sardari, and F. Kobarfard, "Synthesis, antimycobacterial and anticancer activity of novel indole-based thiosemicarbazones," Archives of Pharmacal Research, pp. 1-13, 2013.

[39] I. S. Helm, A. M. Trescot, J. Colson, N. Sehgal, and S. Silverman, "Opioid antagonists, partial agonists, and agonists/antagonists: the role of office-based detoxification," Pain Physician, vol. 11, no. 2, pp. 225-235, 2008.

[40] S. Bimonte, A. Barbieri, M. Cascella et al., "The effects of naloxone on human breast cancer progression: in vitro and in vivo studies on MDA.MB231 cells," OncoTargets and Therapy, vol. 11, pp. 185-191, 2018.

[41] Y. Xing, W. Zhang, J. Song, Y. Zhang, X. Jiang, and R. Wang, "Anticancer effects of a novel class rosin-derivatives with different mechanisms," Bioorganic \& Medicinal Chemistry Letters, vol. 23, no. 13, pp. 3868-3872, 2013.

[42] G. Rangel-Sánchez, E. Castro-Mercado, and E. García-Pineda, "Avocado roots treated with salicylic acid produce phenol-2,4bis (1,1-dimethylethyl), a compound with antifungal activity," Journal of Plant Physiology, vol. 171, no. 3-4, pp. 189-198, 2014.

[43] A. R. Padmavathi, B. Abinaya, and S. K. Pandian, "Phenol, 2,4bis(1,1-dimethylethyl) of marine bacterial origin inhibits quorum sensing mediated biofilm formation in the uropathogen Serratia marcescens," Biofouling, vol. 30, no. 9, pp. 1111-1122, 2014.

[44] J.-Y. Kang, B.-S. Chun, M.-C. Lee, J.-S. Choi, I. S. Choi, and Y.-K. Hong, "Anti-inflammatory activity and chemical composition of essential oil extracted with supercritical CO 2 from the brown seaweed undaria pinnatifida," Journal of Essential Oil Bearing Plants, vol. 19, no. 1, pp. 46-51, 2016.

[45] N. M. Zin, M. S. Baba, A. H. Zainal-Abidin, J. Latip, N. W. Mazlan, and R. Edrada-Ebel, "Gancidin W, a potential low-toxicity antimalarial agent isolated from an endophytic Streptomyces SUK10," Drug Design, Development and Therapy, vol. 11, pp. 351-363, 2017.

[46] X. Zhang, X. Wang, T. Wu et al., "Isoliensinine induces apoptosis in triple-negative human breast cancer cells through ROS generation and p38 MAPK/JNK activation," Scientific Reports, vol. 29, no. 5, article no. 12579, pp. 1-13, 2015.

[47] D. Trachootham, J. Alexandre, and P. Huang, "Targeting cancer cells by ROS-mediated mechanisms: a radical therapeutic approach?" Nature Reviews Drug Discovery, vol. 8, no. 7, pp. 579-591, 2009.
[48] C. Pereira, K. Murphy, and D. Herndon, "Outcome measures in burn care: is mortality dead?” Burns, vol. 30, no. 8, pp. 761-771, 2004.

[49] J. Cumming, G. F. Purdue, J. L. Hunt, and G. E. O'Keefe, "Objective estimates of the incidence and consequences of multiple organ dysfunction and sepsis after burn trauma," Journal of Trauma and Acute Care Surgery, vol. 50, no. 3, pp. 510-515, 2001.

[50] J. H. Calhoun, C. K. Murray, and M. M. Manring, "Multidrugresistant organisms in military wounds from Iraq and Afghanistan," Clinical Orthopaedics and Related Research, vol. 466, no. 6, pp. 1356-1362, 2008. 


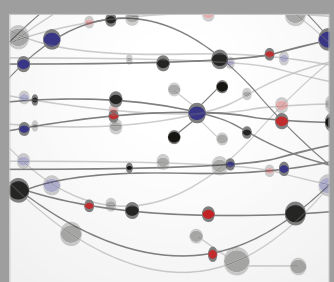

The Scientific World Journal
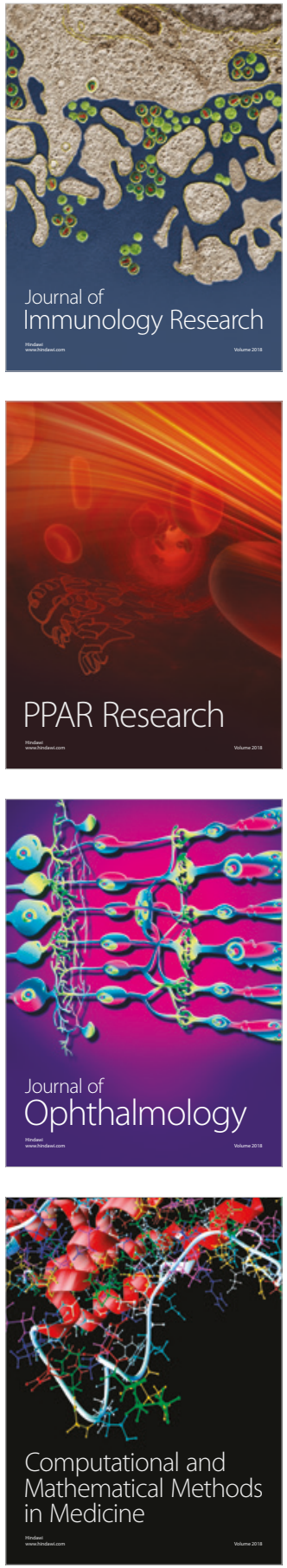

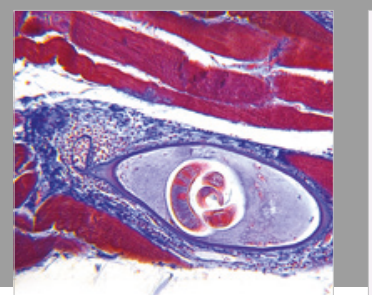

Gastroenterology Research and Practice

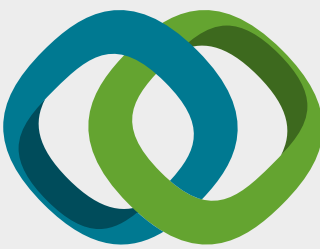

\section{Hindawi}

Submit your manuscripts at

www.hindawi.com
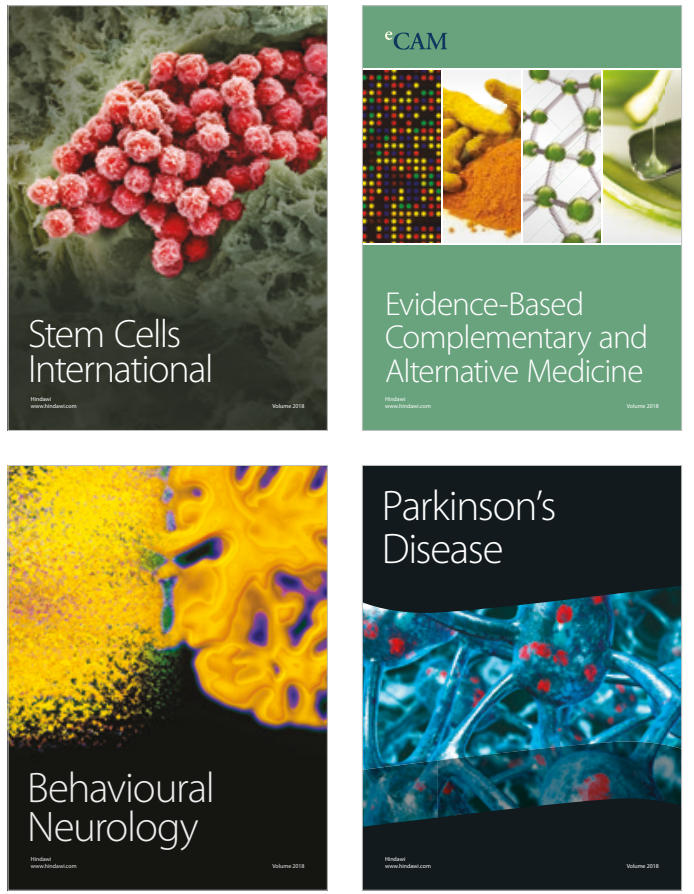

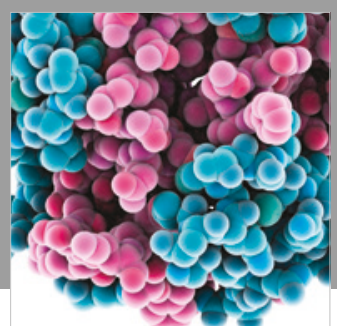

ournal of

Diabetes Research

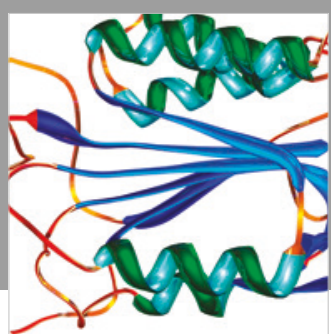

Disease Markers
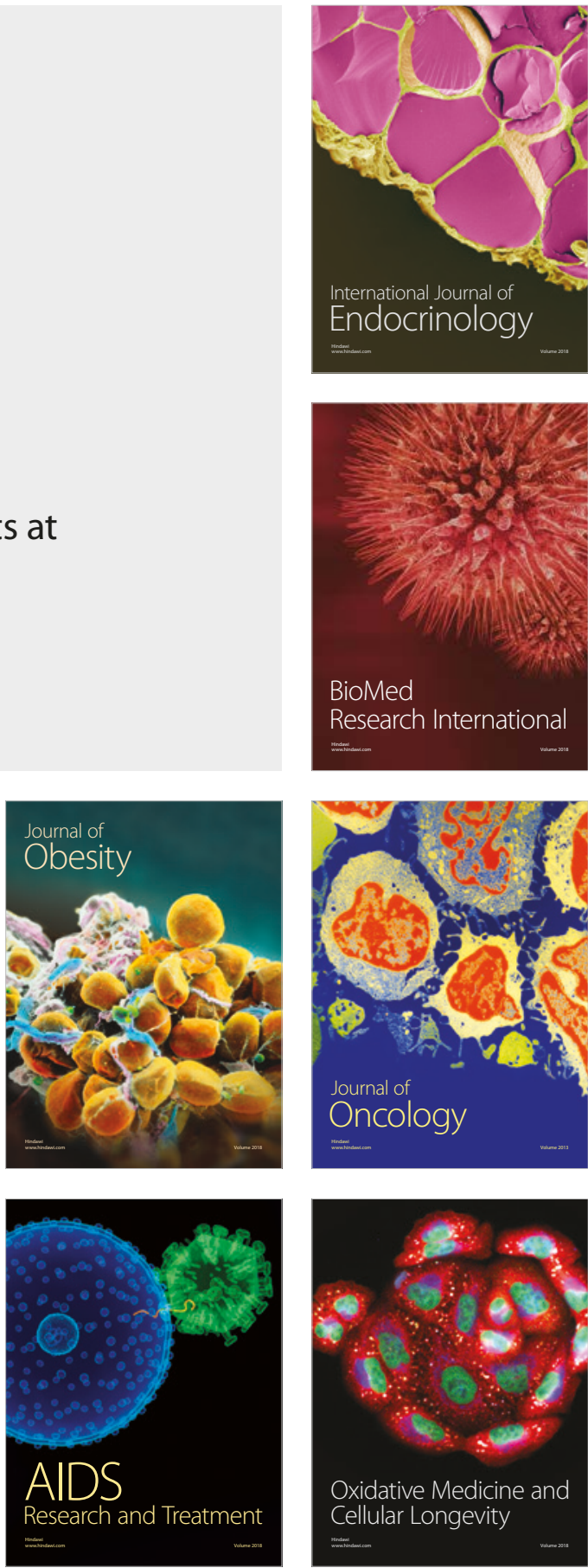